\title{
Continuous veno-venous hemofiltration in patients with metformin associated lactic acidosis
}

\author{
C Bethlehem ${ }^{1 *}$, PHJ van der Voort ${ }^{1,2}$ \\ From ESICM LIVES 2015 \\ Berlin, Germany. 3-7 October 2015
}

\begin{abstract}
Introduction
Metformin is frequently used by type II diabetics. A rare complication of its use is metformin associated lactic acidosis (MALA). This condition is often accompanied by extreme metabolic acidosis and hemodynamic instability for which ICU treatment is mandatory. Guidelines advice intermittent hemodialysis for correction of metabolic acidosis and to clear metformin. However, haemodynamic instability may prefer continuous veno-venous hemofiltration $(\mathrm{CVVH})$. We evaluated the effect of $\mathrm{CVVH}$ in critically ill patients admitted with MALA.
\end{abstract}

\section{Methods}

We performed a retrospective single centre cohort study in a 20-bed mixed ICU. All consecutive patients admitted with clinical diagnosis of metformin intoxication between January 2010 and December 2014 were included. Data were extracted from the local Patient Data Management System and analysed with SPSS 21.0. Data are presented as median and IQR or mean $\pm \mathrm{SD}$.

\section{Results}

10 patients were identified. $80 \%$ were male, median age was 68 years (IQR 65-77). Apache II was 30.5 (IQR 27$34)$, corresponding with a predicted mortality of $65 \%$ (IQR 39-83). The first measured serum metformin level $(\mathrm{N}=6)$ was 32 (IQR 14-50). Nine cases were due to chronic accumulation of metformin and one was an acute intoxication. Metformin accumulation could be explained by renal impairment caused by dehydration $(\mathrm{N}=4)$, infection $(\mathrm{N}=3)$ or medication $(\mathrm{N}=2)$. Mean $\mathrm{pH}$ at admission was 7.08 ( $\mathrm{SD} \pm 0.136)$, highest measured lactate was $13.95 \mathrm{mmol} / \mathrm{l}$ (IQR 10-21). Continuous veno-venous hemofiltration was initiated in 8 out of 10 patients, the other 2 patients had a $\mathrm{pH}$ above 7.20.

${ }^{1}$ Onze Lieve Vrouwe Gasthuis, Intensive Care, Amsterdam, the Netherlands Full list of author information is available at the end of the article
CVVH was administered in high volume post-dilution mode with citrate anticoagulation. Dosage of $\mathrm{CVVH}$ was $54.89 \mathrm{ml} / \mathrm{kg} /$ hour (IQR 50.8-61.1). Time to normalisation of $\mathrm{pH}$ was 557.5 minutes (IQR 285-840), median duration of CVVH was 35.67 hours (IQR 17-75.33). In three patients the serum level was repeatedly measured and showed a decline. A mean arterial pressure of $60 \mathrm{mmHg}$ was achieved with a maximum concentration of $0.08 \mathrm{mcg} / \mathrm{kg} / \mathrm{min}$ norepinephrine (IQR $0-0.29$ ) and $5.6 \mathrm{mcg} / \mathrm{kg} / \mathrm{min}$ dopamine (IQR 2.2-9.8). The two oldest patients died, one because of termination of renal replacement therapy in end-stage kidney disease due to tubulointerstitial nephritis (79 years), the second because of refractory septic shock ( 85 years).

\section{Conclusions}

$\mathrm{CVVH}$ was effective in restoring acid base disorders and haemodynamics in patients with MALA and hypotension. It appears to be a safe alternative to intermittent hemodialysis.

\section{Authors' details}

'Onze Lieve Vrouwe Gasthuis, Intensive Care, Amsterdam, the Netherlands.

${ }^{2}$ TIAS School for Business and Society, Tilburg, the Netherlands.

Published: 1 October 2015

\section{References}

1. Kajbaf F, Lalau JD: Mortality rate in so-called "metformin-associated lactic acidosis": a review of the data since the 1960s. Pharmacoepidemiol Drug Saf 2014, 23(11):1123-1127.

2. Keller G, Cour M, Hernu R, Illinger J, Robert D, Argaud L: Management of metformin-associated lactic acidosis by continuous renal replacement therapy. PLoS One 2011, 6(8)-e23200.

3. Nguyen $\mathrm{HL}$, Concepcion L: Metformin intoxication requiring dialysis. Hemodial Int 2011, 15(Suppl 1):68-71.

doi:10.1186/2197-425X-3-S1-A464

Cite this article as: Bethlehem and van der Voort: Continuous venovenous hemofiltration in patients with metformin associated lactic acidosis. Intensive Care Medicine Experimental 2015 3(Suppl 1):A464.
(C) 2015 Bethlehem et al.; This is an Open Access article distributed under the terms of the Creative Commons Attribution License (http://creativecommons.org/licenses/by/4.0), which permits unrestricted use, distribution, and reproduction in any medium, provided the original work is properly cited. 